\title{
ヨシを用いた水際保護の研究 STUDY ON RIPARIAN PROTECTION USING SOIL MASS COVERED WITH REEDS
}

\author{
福岡捷二 $^{1} \cdot$ 福田朝生 $^{2} \cdot$ 永井慎也 $^{3} \cdot$ 小谷哲也 $^{4} \cdot$ 富田紀子 ${ }^{5}$
}

Shoji FUKUOKA, Tomoo FUKUDA, Shinya NAGAI, Tetsuya KOTANI and Noriko TOMITA

\author{
1 フェ一会員 工博 Ph.D 広島大学大学院教授 社会環境システム専攻 (テ739-8527 広島県東広島市鏡山 1-4-1) \\ 2 学生会員 広島大学大学院 工学研究科 社会環境システム専攻 博士課程前期 (同上) \\ 3 学生会員 広島大学 工学部 第四類 (同上) \\ 4 正会員 国土交通省中国地方整備局 出雲工事事務所 (下693-0023 島根県出雲市塩冶有原町 5 丁目 1 番地) \\ 5 正会員 国土交通省中国地方整備局 中国技術事務所（广736-0082 広島県広島市安芸区船越南 2-8-1)
}

\begin{abstract}
At the present it has been clarified that soil masses covered with reeds that had fallen from the banks are not easily transported and still protect banks by reducing the flow velocity surrounding them. Therefore, this study aims to develop riparian protection measures against bank erosion using soil masses covered with reeds by placing them along river bank at an streamwise intervals. Two experiments on erosion have been done by using undisturbed soil masses covered with reeds that were obtained from the field. One is made by observing the erosion of soil masses one by one in a laboratory experiment. The other is made in at a channel for agricultural use of Hii river to observe an erosion of soil masses for longer period by placing some soil blocks longitudinally along the river bank. The reeds' density resisting the erosion of soil mass is found from the experiments. Moreover, it is proved that soil masses covered with reeds can be available for riparian protection for a long period.
\end{abstract}

Key Words : reeds, fallen soil block, riparian design

\section{1. 序論}

ヨシで覆われた河岸は，ヨシの地下茎が土を保持する ため, 護岸効果が認められる. 本研究ではヨシの護岸効 果を水際設計へ応用していくことを目的としてている。著 者らは ${ }^{1), 2), 3) ~}$ 図-1 に示すヨシ原河岸の侵食過程を調べ た. ヨシ原河岸の地表面付近は地下茎が匍匐しているた め侵食抵抗が大きく侵食は地下茎の少ない河岸下部から 進行しひさし状河岸を形成する.ひさし状が進行し, 河 岸から崩落したヨシの根を含む土塊は, 水中にあっても その大きさが比較的長時間保持される. その結果, 近傍 の河岸流速を低下させその後の河岸侵食を抑制する効果 がある.また，ヨシ原河岸では崩落しても土塊が河岸際 に残るため河岸は縦断的に凹凸形状を呈する特徵を持つ. このようにヨシ原河岸に護岸効果が生じる原因は二つあ る. 一つは河岸自体がヨシ地下茎により耐侵食性が増す ことと, 他の一つは崩落したヨシを含む土塊が水中に長 時間保持され河岸近傍の流速を低下させることである. ここでは後者に着目する.ヨシを含む土塊をある間隔で

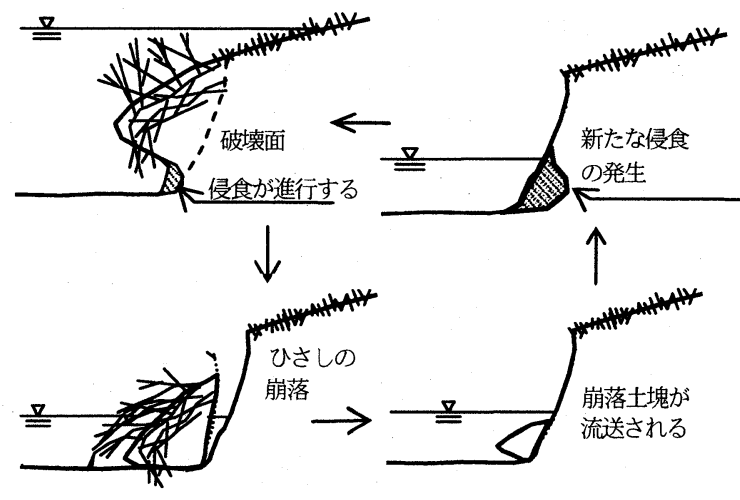

図-1 ヨシ原河岸の侵食過程

流水中に設置し，河岸近傍の流速を低下させることによ り自然河岸の侵食を防ぐこと, また, 直線的な河岸に凹 凸を持たすことで洪水時でも流速の低い箇所を水際につ くり，生物の生息·避難場所を提供することも期待する. このような護岸方法を本研究ではヨシ原護岸と呼ぶこと にする. 本研究では始めにヨシの密度によって土塊がど の程度の耐浸食性を示すか, どのような浸食過程をたど るのか水理実験で把握してヨシ原護岸の設計のための基 


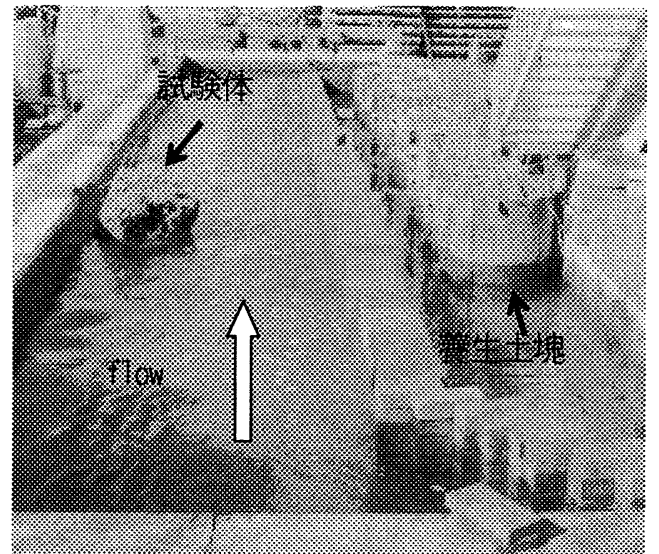

図-2 実験風景

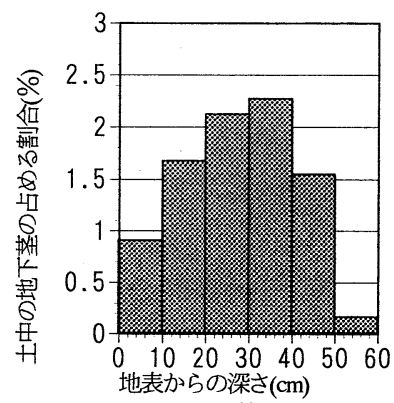

図-4 地下茎分布
表-1 ヨシの密度

\begin{tabular}{|c|c|}
\hline 土塊番号 & $\begin{array}{c}\exists シ の \text { 密 度 } \\
\left(\text { 本 } / \mathrm{m}^{2}\right)\end{array}$ \\
\hline 土塊 1 & 0 \\
\hline 土塊 2 & 0 \\
\hline 土塊 3 & 90 \\
\hline 土塊 4 & 100 \\
\hline 土塊 5 & 130 \\
\hline 土塊 6 & 170 \\
\hline 土塊 7 & 400 \\
\hline
\end{tabular}

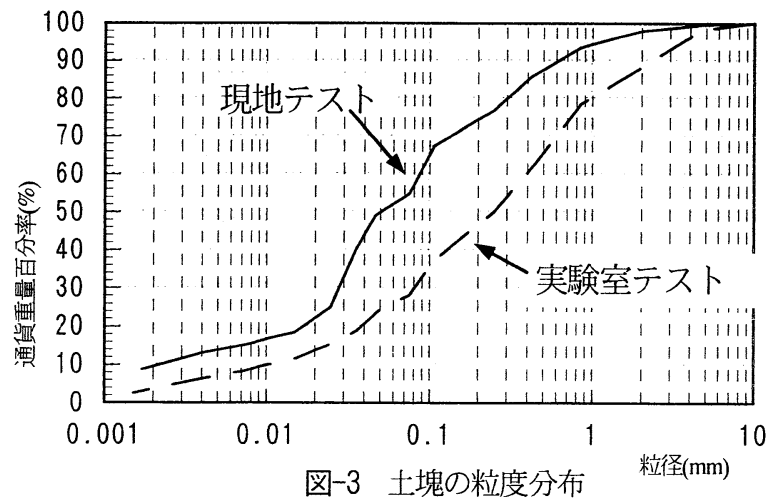

表-2 実験ケース

\begin{tabular}{|c|c|c|c|c|c|}
\hline & $\begin{array}{c}\text { 土塊の } \\
\text { 番号 }\end{array}$ & $\begin{array}{c}\text { 水路幅 } \\
(\mathrm{cm})\end{array}$ & $\begin{array}{c}\text { 水深 } \\
(\mathrm{cm})\end{array}$ & $\begin{array}{c}\text { 平均流 } \\
\text { 速 }(\mathrm{cm} / \mathrm{s})\end{array}$ & $\begin{array}{c}\text { 通水時 } \\
\text { 間 }(\mathrm{h})\end{array}$ \\
\hline case1 & 3 & 105 & 19 & 36 & 3.1 \\
\hline case2 & 3 & 105 & 22 & 59 & 0.7 \\
\hline case3 & 4,7 & 105 & 29 & 51 & 2 \\
\hline case4 & 4,7 & 105 & 29 & 51 & 1.8 \\
\hline case5 & 4,7 & 105 & 31 & 51 & 1.4 \\
\hline case6 & 4,7 & 105 & 29 & 61 & 4.2 \\
\hline case7 & 4,7 & 105 & 29 & 94 & 1.3 \\
\hline case8 & 7 & 80 & 44 & 92 & 4 \\
\hline case9 & 7 & 80 & 41 & 99 & 3.8 \\
\hline case10 & 7 & 80 & 41 & 99 & 3.8 \\
\hline case11 & 6 & 140 & 24 & 61 & 48 \\
\hline case12 & 5 & 140 & 24 & 61 & 16 \\
\hline
\end{tabular}

礎資料を得る。実験方法はヨシの根を含む不擋乱の土塊 を採取して通水し形状の変化を調べるものである. しか し，この方法では形状の変化を長時間にわたって観察で きないこと, 縦断距離が短く十分な間隔を空けて土塊を 設置できないこと等のため土塊の縦断的な浸食形態が観 察できない課題が残された。そこで，長時間かつ，縦断 的に長い距離に亘って土塊を配置できるようヨシ原護岸 を斐伊川農業用水路に設置し，観測を行い，ヨシ原護岸 の有用性を検討するための資料を示している。

\section{2. 水理実験による検討}

\section{（1）実験方法}

ここでは実現象の崩落土塊と同程度の大きさのヨシの 根を含んだ不擋乱の供試体を採取して流水による浸食実 験を行った.供試体は直径 $50 \mathrm{~cm}$ 高さ $60 \mathrm{~cm}$ の円柱型であ り，ヨシの繁茂する太田川放水路の高水敷から採取し用 いた. 水路は水路長 $10 \mathrm{~m}$ 水路幅 $0.8 \sim 1.4 \mathrm{~m}$ 勾配 $1 / 500$ の開水路である. 実験方法は, 図-2 に示すようにヨシの 根を含む土塊を水路左岸側に接触させるように設置し， 通水する．時間の経過と共に土塊の形状を測定し，土塊 周りの流れを電磁流速計を用いて測定する。土塊上面の ヨシの本数(ヨシの密度 $\left(\right.$ 本 $\left.\left./ \mathrm{m}^{2}\right)\right)$ が地下茎の量を代表して いると考え浸食速度に対する指標とした。土塊は，全部 で7体である. 土塊中のヨシの密度を表-1に示す. 採取
したヨシを含んだ土塊の平均のヨシの密度は 190 本 $/ \mathrm{m}^{2}$ である.土塊を構成する土の粒度分布を図-3に示す.土 質はシルト質砂で粘土含有率は 7\%である. 図-4 に実験 で使用した土塊の地下茎分布の代表としてヨシの密度 260 本 $/ \mathrm{m}^{2}$ の土塊の土中の地下茎の占める割合と地表から の深さの関係を示す. 深さ $50 \mathrm{~cm} \sim 60 \mathrm{~cm}$ の範囲で地下茎 が大きく減少しており，その範囲では浸食抵抗が若干弱 いことが考えられる. 実験ケースを表 2 に示す. 平均流 速は土塊横の横断面の平均流凁を採用した。

\section{（2） 実験結果及び考察}

\section{a）土塊浸食の機構}

ヨシの密度の小さい土塊から浸食・流送の状況を説明す る.まず，ヨシがまったく生えていない2 体の土塊のう ち 1 体は強度がなく設置時に崩壊し細分化した. もう 1 体も設置はできたが通水開始直後に崩壊し細分化した。 このことは, 用いた土塊の浸食抵抗は, 極めて小さいこ とを示す. ヨシ密度 90 本 $/ \mathrm{m}^{2}$ の土塊 3 は通水から 3 時間 40 分後に崩壊し細分化した. 100 本 $/ \mathrm{m}^{2}$ の土塊 4 は通水 後 1 時間 30 分後に水路中央側に倒れたが，地下茎によ り土塊が保持され細分化することはなく, 円柱の形状を 保っていた. 130 本/ $\mathrm{m}^{2}$ の土塊 5 は通水開始から 16 時間 後に水路中央側に倒れたが細分化はしなかった.ヨシ密 度 170 本 $/ \mathrm{m}^{2}$ の土塊 6 は合計で 48 時間通水したが浸食は ほとんど進まず，最後まで自立していた. 400 本 $/ \mathrm{m}^{2}$ の土 塊 7 も合計で 22 時間通水したがほとんど浸食されず, 


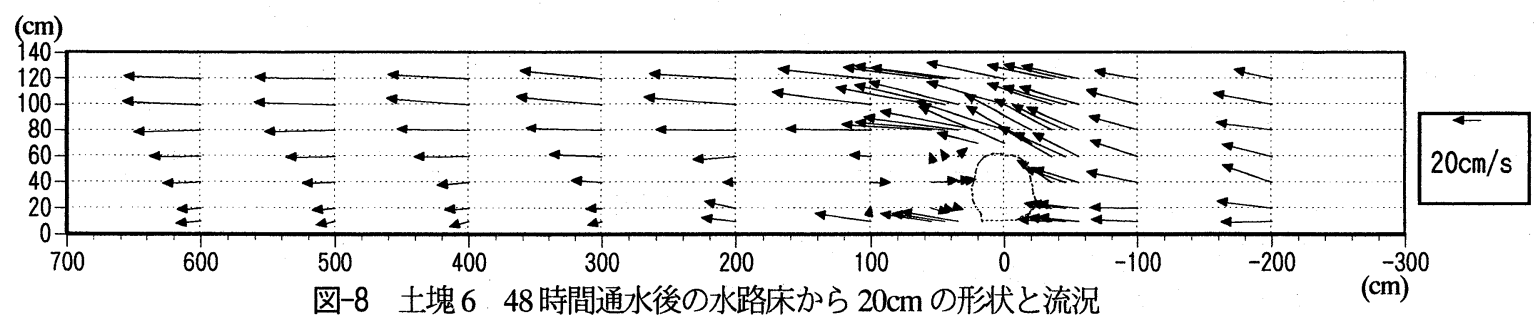

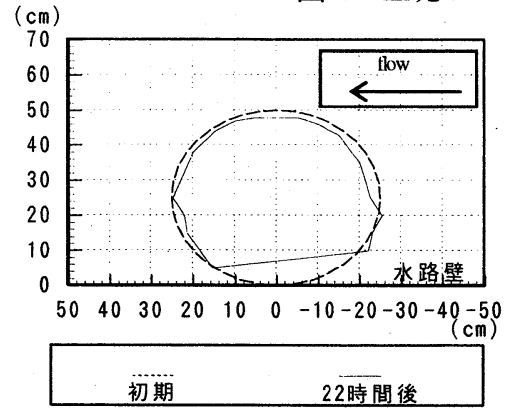

図-5 水路床から高さ $5 \mathrm{~cm}$ の形状

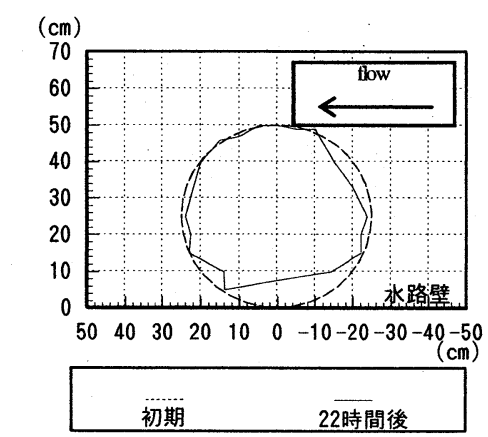

図-6 水路床から高さ $40 \mathrm{~cm}$ の形状

最後まで自立していた.これより，ヨシを十分に含む土 塊は流水中でも長時間自立することが明らかとなった。

次に図-5，図-6 に示す土塊 7 の形状より，長時間自 立した土塊の浸食状況を述べる. 浸食が顕著に進行する 場所は大きく分けて三つある. 第一は土塊下部の水路中 央側, 第二は水路壁と土塊の間, 第三は水面付近の水路 中央側のやや上流側である.土塊下部の水路中央側の浸 食の進行により土塊は流心側に傾き，その結果水路壁と 土塊の間で流れが集中し流速が増大する傾向が見られ た.この箇所の流速の増大は実際にヨシ原護岸を施工し た場合, 河岸が土塊によって侵食される可能性があるこ とを示している.したがって実際に施工する際には設置 する土塊と土塊の間隔をある一定の範囲内にし, 土塊と 土塊の間で流速を低下させ, 河岸付近で土塊に対する接 近流速を遅くする必要がある. また，土塊下部は図-4 で示したように地下茎が少ないために浸食が進行しゃ すい.

土塊の浸食の時間経過を図-7 に示す．図を見ると 90 本 $/ \mathrm{m}^{2}$ の土塊は急速に浸食を受け，体積が減少している 事がわかる. また，最後まで自立していたヨシの密度が 170 本 $/ \mathrm{m}^{2}$ と 400 本 $/ \mathrm{m}^{2}$ の土塊は, 初期の段階で多少浸食 されるものの, ある程度時間が経過するとそれ以上浸食 されないことがわかる。

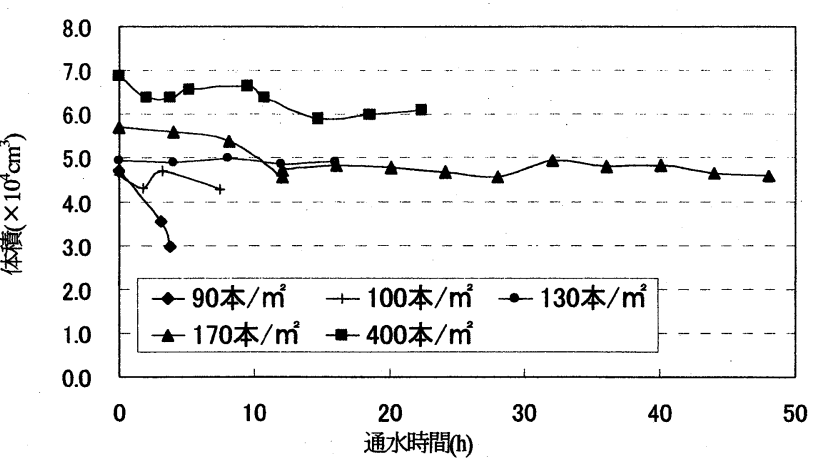

図-7 残存体積と通水時間の関係

b) 土塊近傍の流れ

土塊 6 の 48 時間後の形状とそのときの流れの状況を 図-8 に示す. 土塊背後では流速が低下している. 左岸 から $10 \mathrm{~cm}$ の位置の流速を流下方向に追っていくと，土 塊近傍の上流側で一旦低下するものの土塊と河岸の間 で急に増大し，土塊直下流では土塊上流の接近してくる 流速より大きくなっている. しかしさらに流下すると土 塊背後の剥離域と混合して左岸付近の流速は大きく低 下する. また，低下した流速はなかなか回復していない ことがわかる.

\section{3. 斐伊川左岸農業用水路での検討}

\section{（1）施工方法}

ヨシ原護岸の現地での検討は斐伊川左岸の高水敷上の 農業用水路で平成 14 年 7 月 5 日から行った。試験区間の 左岸はコンクリート護岸,右岸はカゴマットを三段積み した護岸が施工され,水路線形はほぼ直線である.ヨシを 含む土塊の大きさや設置間隔は同じ用水路でのヨシ原河 岸の崩落観測より得られた諸元を参考に決めた ${ }^{1)}$. 即ち, 土塊と土塊の間隔は $9 \mathrm{~m}$ とし, 土塊寸法は実際の崩落し ている土塊の大きさ約 $3 \mathrm{~m}$ に近づけるように縦断長さ $1 \mathrm{~m}$ の土塊 3 体を 1 つの大きな土塊に見立てて縦断的に近接 して設置した. 図-9に土塊の寸法，図-10に設置区間平 面図，図-11 に設置区間の断面図を示す.並べて設置し た縦断長さ $3 \mathrm{~m}$ の土塊の名称を土塊群とし，上流から土 塊群 $\mathrm{A}, \mathrm{B}, \mathrm{C}, \mathrm{D}, \mathrm{E}$ と呼ぶ. 縦断長さ $1 \mathrm{~m}$ の個々の土 塊を上流からそれぞれ1体目，2体目，3体目と名付ける。 A の 1 体目を A-1 で表す. 図-11 に示すようにヨシ原護 岸はカゴマット護岸前面に設置することのみを対象とし 
$\begin{array}{lllll}\text { E } & \text { D } & \text { C } & \text { B } & \text { A }\end{array}$

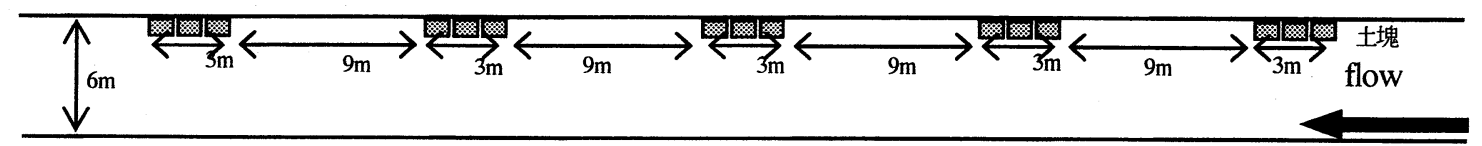

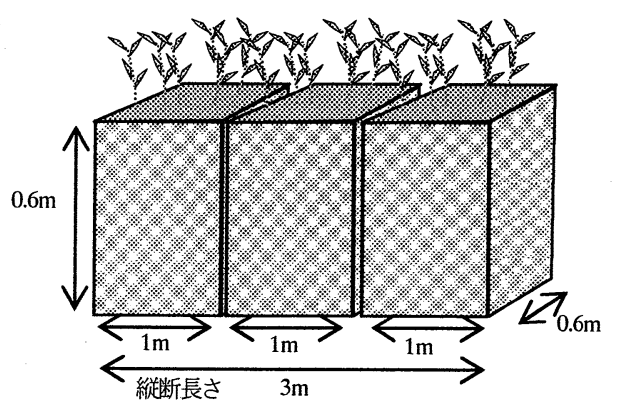

図-9 土塊の寸法

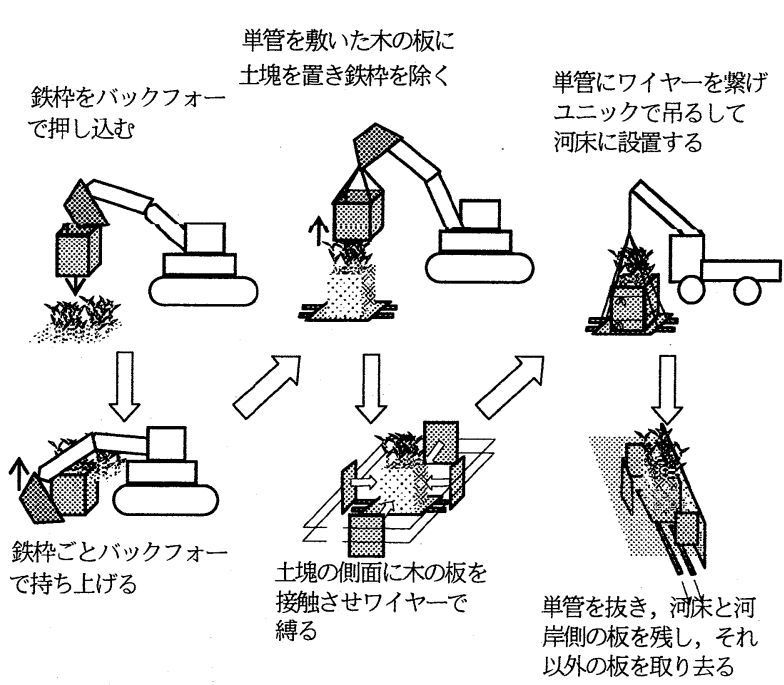

図-12 土塊の採取と設置方法

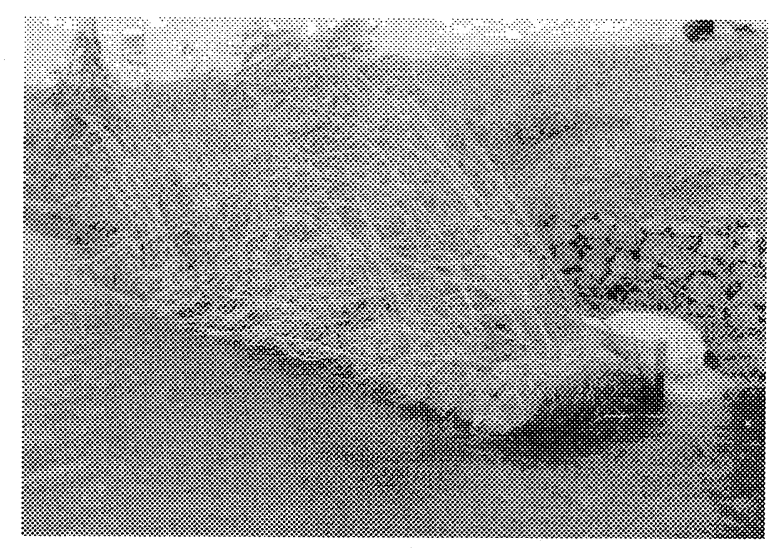

図-14 ヨシを持つ土塊の設置状況(撮影日7月 6日)

ていないので, カゴマット内からの流れによって土塊が 浸食されることを防ぐため, 土塊採取時に用いた枠板を 底面と河岸側だけ残してカゴマットに緊結している。ま た, 土塊と河岸の間の流れを防ぐため土囊を盛って土塊 と河岸の間を止水している. 土塊の切り出しは斐伊川高 水敷上では砂が多く, 土塊が自立しなかったため粘土含 有率の高いヨシの繁茂している宾道湖湖岸よりを採取し た. 切り出した土塊を構成する土の粒度分布を図-3に示

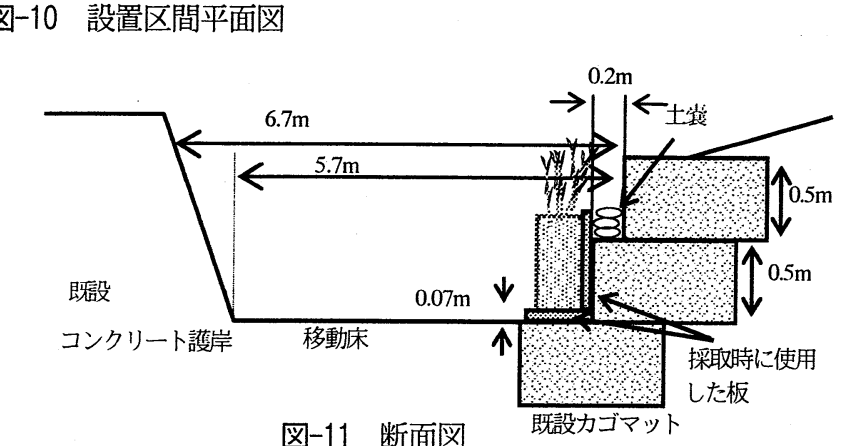

図-11 断面図

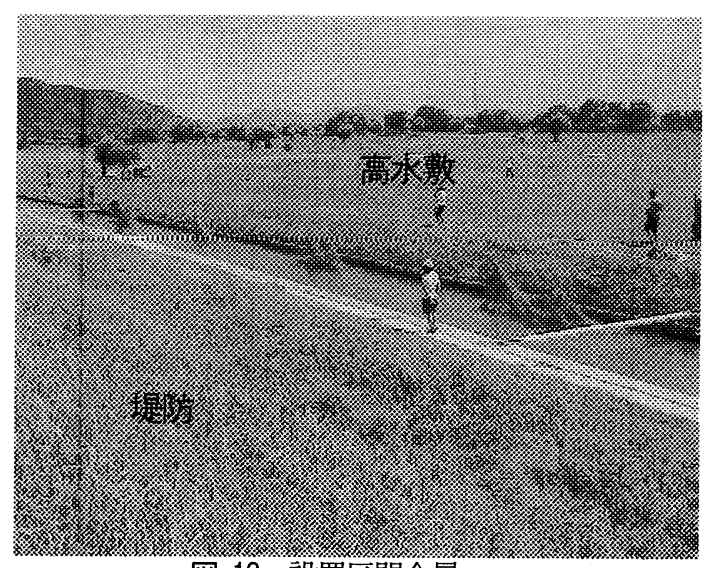

図-13 設置区間全景

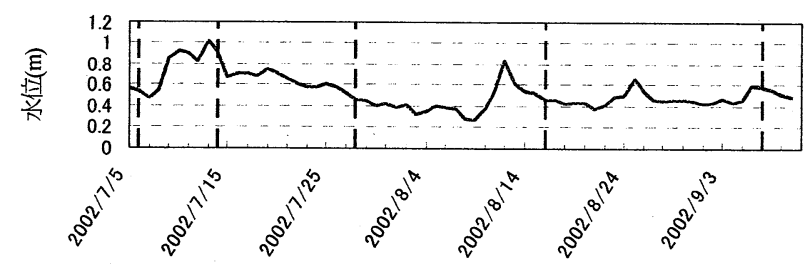

図-15 設置区間の水位

す.土質はシルト質砂で粘土含有率は $14 \%$ である.土塊 の採取と設置方法を図-12 に示す. 設置した区間の全景 を図-13 に設置した土塊の近景を図-14 に示す. 2節で示 したヨシの根を含む土塊の浸食実験よりヨシの密度によ って土塊の浸食される過程が異なる事がわかった。この ためヨシ原護岸の施工にはできるだけ各土塊群でヨシの 密度の差がつかないような土塊を選び設置した. 各土塊 上面のヨシの密度を表-3に示す. 全土塊の平均のヨシの 密度は 190 本 $/ \mathrm{m}^{2}$ あ゙る.

\section{（2）観測結果及び考察}

a) 水位と平均流速

設置位置での水位の時間変化を図-15 に示す. 用水路 の平常時の水深は約 $50 \mathrm{~cm}$ 程度で土塊の上面部は水面よ り約 $10 \mathrm{~cm}$ 程度高い位置にある. 斐伊川は毎年 1,2 回高 水敷に冠水する.今回も 7 月 9 日から 7 月 14 日まで水位 

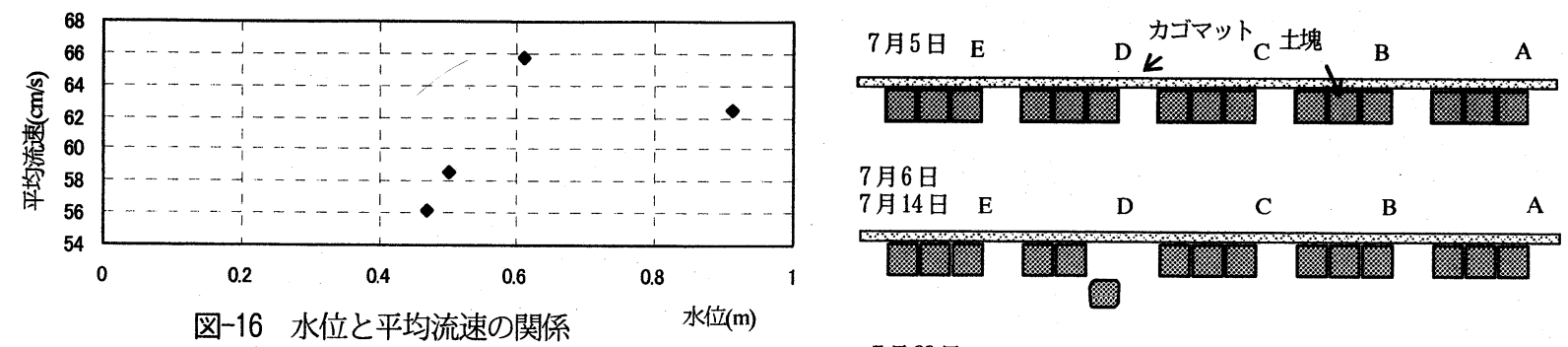

表一3 ヨシの密度

\begin{tabular}{|c|c|c|c|c|}
\hline & 1 体目 & 2体目 & 3体目 & 平均 \\
\hline A & 185 & 192 & 108 & 192 \\
\hline B & 228 & 152 & 202 & 194 \\
\hline O & 168 & 247 & 165 & 192 \\
\hline D & 30 & 248 & 273 & 184 \\
\hline E & 235 & 163 & 168 & 192 \\
\hline
\end{tabular}

$\left(\right.$ 本 $\left./ \mathrm{m}^{2}\right)$
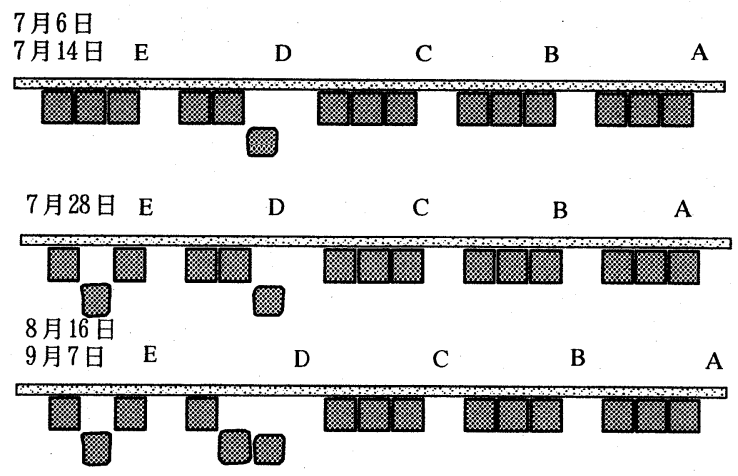

図-17 土塊の状況

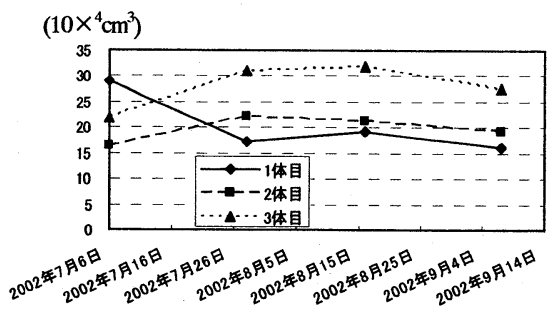

図-18 土塊 $\mathrm{A}$ の体積

$\left(10 \times{ }^{4} \mathrm{~cm}^{3}\right)$

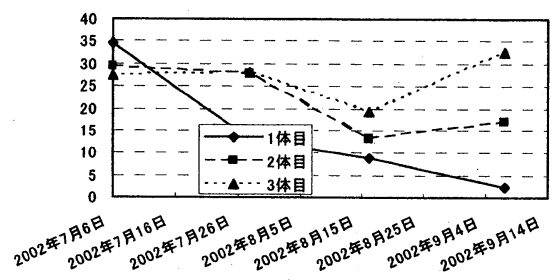

図-21 土塊 D の体積

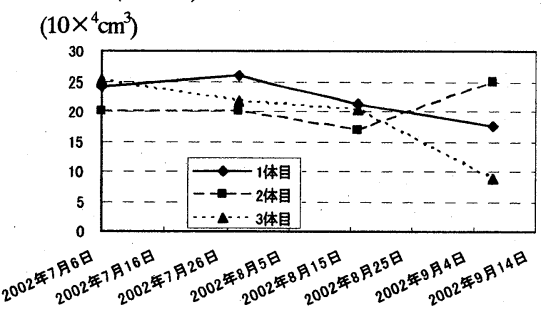

図-19 土塊 B の体積

$\left(10 \times{ }^{4} \mathrm{~cm}^{3}\right)$

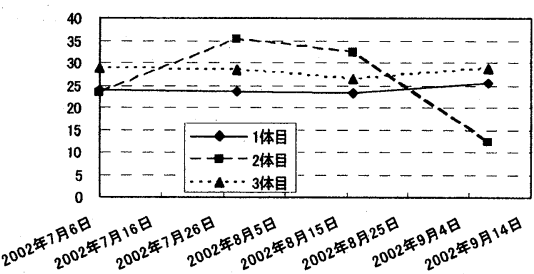

図-22 土塊 $\mathrm{E}$ の体積

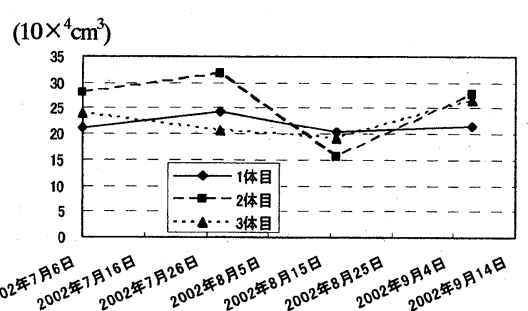

図-20 土塊 C の体積

$\left(10 \times \mathrm{cm}^{3}\right)$

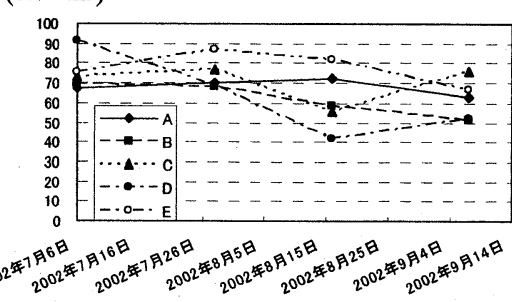

図-23 土塊群の体積
の高い状態が続いておりその間は土塊の上面が水没した 状態となっている. 観測日は図中の縦線に示すように， 平成 14 年の 7 月 6 日，14 日，28 日，8月 16 日，9月 7 日で試験期間は約 3 ケ月間である. 平均流速水位との関 係を図-16 に示す. 水位変化によって平均流速は $10 \mathrm{~cm} / \mathrm{s}$ 程度しか変化していないため土塊の浸食に及ぼす流速の 影響の変化は小さいと考えられる。

b) 土塊の状況

図-17 に土塊の状況を示す.土塊は 7 月 5 日の設置時 には全て自立していた.しかし，7月6日にはD-1の土 塊が河道中央側に向かって倒れていた. D-1 が最初に倒 れた原因は，ヨシの密度が 30 本 $/ \mathrm{m}^{2}$ と極端に小さく強度 がなかったためと考えられる.また，流心側に倒れた原 因は実験室での結論より推測がつく.即ち, 流速が速く, かつヨシ地下茥の少ない河道中央側の土塊下部が浸食を 受けたためだと考えられる. 次に 7 月9日小らの大さな 出水の後の7月14日までの間土塊の状況は大きくは変化 していなかった.7月 28 日の観測では，E-2 が河道中央 側に倒れていた. E-2 も 3 番目にヨシの密度が小さい土 塊であるため倒れた原因はヨシの密度が小さいためであ
ると考えられる. 8 月 16 日の観測では, 新たに D-2 が河 道中央側に向かって倒れていた。この土塊はヨシの密度 が大きい方で, 土塊中の地下茎が他と比べて少なかった とは考えにくい. したがって D-1 の土塊が倒れたことに より D-2 の周りに比較的速い流れが生じ, 浸食の進行が 起こったと考えられるが，そのことについては現在のと ころはっきりとした原因が不明である. なお, 実験室内 での結果と比較して用水路の試験では土塊を群として設 置したため, 河岸近傍の流速が大きくなりにくく, 土塊 と河岸の間の浸食は見られない。

次に各土塊の体積の時間変化を図-18〜図-22 に示す. 土塊の形状は水中で計測しているため䛊差を含んでいる. しかし，特徵的な傾向は捉えている。 まず，7月 6 日に 倒れていた D-1 はヨシの密度が 30 本 $/ \mathrm{m}^{2}$ と小さいとも あり，急速に体積が減少している事がわかる. また， 7 月 28 日に倒れていた E-2 はヨシの本数が 163 本 $/ \mathrm{m}^{2}$ と多 少あることから始めは浸食が緩やかであるがやはり河道 中央側に倒れてからは他の土塊と比べて浸食速度は速い。 8 月 16 日に倒れていた D-2 はヨシの密度が 248 本 $/ \mathrm{m}^{2}$ と 比較的大きいことや倒れてからの期間が短いため, 顕著 
(m)

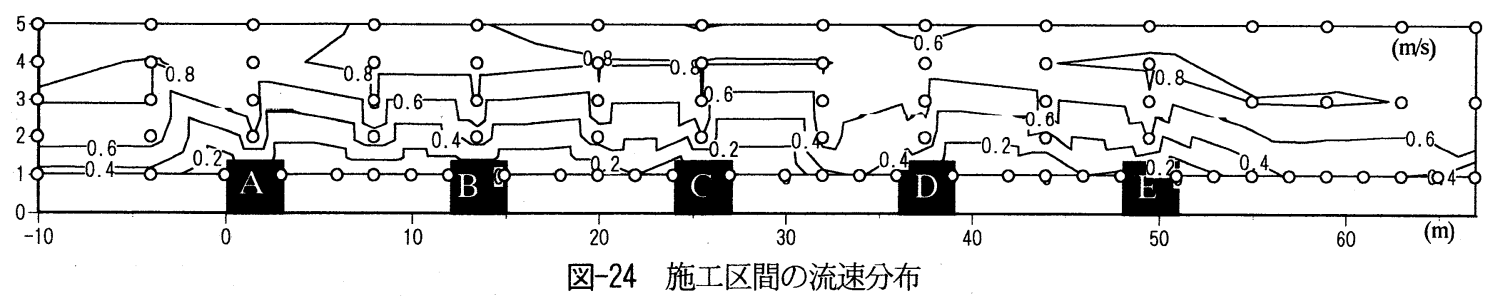

な体積の減少は見られない。図-23 に土塊群の体積を示 す.土塊 D は若干浸食を示しているがそれ以外の土塊は 浸食が小さい.また，他の土塊と比べて外力の大きさが 異なる土塊群 $\mathrm{A}$ ，土塊群 $\mathrm{E}$ など設置区間の端の土塊群は これまでのところ特徵的な浸食傾向は見せていない。

\section{C）施工区間の流れ場}

図-24 に用水路の施工区間の流速コンターを示す．流 速の計測は図中の白丸の点で水位が $60 \mathrm{~cm}$ のときに水面 下 $30 \mathrm{~cm}$ の位置でプライス流速計を用いて行った.ヨシ原 護岸を設置した区間では土塊背後に流速の低い箇所がで きている.この区間には，多くの小魚が群れるようにな った.土塊の設置間隔は 9m であるが河岸近傍の流速は回 復しておらず，河岸を守る効果は十分であると考えられ る.土塊群 $\mathrm{E}$ の背後には土塊がないために約 $6 \mathrm{~m}$ で施工区 間上流の流速分布に回復している事がわかる.

\section{4. 結論}

水中に崩落した状況を想定したヨシの根を含む土塊の

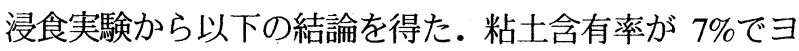
シの密度が 170 本 $/ \mathrm{m}^{2}$ 程度のヨシ原河岸の崩落土塊は水 流による浸食量は小さく流送されにくいことがわかった.

また，斐伊川左岸農業用水路のヨシ原護岸の試験施工 及び 3 ケ月の観測よりヨシ原護岸の有用性をしめす資料 を得た. 土塊の浸食速度は河川の流速, 土質構造, ヨシ の密度差により変化するが, 今回は河川の平均流速が $60 \mathrm{~cm} / \mathrm{s}$ ，土質を粘土含有率が $14 \%$ のシルト質砂とし，ヨ シの密度が 190 本 $/ \mathrm{m}^{2}$ という条件のもと得られた土塊群 の平均浸食速度は約 $2500 \mathrm{~cm}^{3} /$ day である. したがって今 回のように土塊群として $60 \mathrm{~cm} \times 60 \mathrm{~cm} \times 100 \mathrm{~cm}$ の土塊 3 体を並べて設置したとすると，単純計算で約 400 日で無 くなる計算になる.なお, 水理実験ではヨシの密度が 170 本/m²土塊はほとんど浸食されないことがわかったが， 現地試験ひヨシ原護岸を施工した区間では D-2などヨシ の密度の大きい土塊が倒れるなどヨシの密度だけでは やはり確実な浸食状況を予測することができない。しか し, B-2 の 152 本/ $/ \mathrm{m}^{2}$ の土塊や $\mathrm{C}-1$ の 163 本/ $\mathrm{m}^{2}$ の土塊はほ とんど浸食傾向を示していない。したがって水理実験と 約 3 ケ月間の現地試験を総合した結論として，おおよそ 170 本 $/ \mathrm{m}^{2}$ 以上のヨシの密度であれば, 土塊は浸食や倒れ ることは簡単には起こらず，河岸を守る効果が大きい事 が確認された。
また，水理実験，現地試験とも土塊の平均のヨシ密度 は 190 本 $/ \mathrm{m}^{2}$ 程度であることからヨシ原河岸には十分な 護岸効果があると判断される.

\section{5. 今後の課題}

水理実験，現地試験によってヨシ原護岸はかなりの安 定性を持つ事がわかったが，自然の材料を利用した護岸 方法のため土塊の浸食は避けられない。したがって土塊 が流送された区間に新たにヨシを含んだ土塊を補給す るなど定期的な管理が必要となる．そのため，ヨシを含 んだ土塊をいつでも採取できるようにヨシ原の生育ヤ 一ドを高水敷上などに確保する必要がある.

設計・施工方法など害用化に向けた今後の課題として は長期的な調查を継続し，土塊の浸食の過程を把握する 必要がある. 今回は固定床上に土塊を設置したが河床が 移動床であるときに安定した設置方法や土塊下部の河 道中央側の浸食の進行で土塊が倒れないような設置方 法も考えていかなければならない。また，土塊の寸法， 設置間隔の最適な諸元等を求め，さらに土質構造と浸食 の関係も把握する必要がある.さらに単にヨシといえど も種は多様であり生育状態も異なるので今後は実験，モ ニタリング等を通して，ヨシ原護岸の安定性に対するこ れらの影響を検討していく必要がある.

環境面では現地の試験区間において景観の向上，魚な どのハビタットの提供などの面で明らかに改善されて いた. 今後はそのような環境面でのヨシ原護岸の効果も 調査していく必要があり, 最終的に治水面, 環境面, 景 観を考慮し総合的に優れたヨシ原護岸の設計法を確立 していく事が必要となる。

\section{参考文献}

1）福岡捷二，渡邊明英，柏木幸則，山縣聡: ヨシで覆われた 河岸の洪水流による侵食と流路の変動過程, 第 4 回河道の 水理と河川環境に関するシンポジウム論文集, pp83-88

2) 仲本吉宏, 福岡捷二, 佐藤勝利, 富田紀子, 山縣聡: 水位 の変化によるヨシ原河岸の崩落機構, 土木学会第 55 回年次 学術講演会講演概要集(CD-ROM), II-265，2000-9

3) 福岡捷二, 仲本吉宏, 石上鉄雄, 福田朝生 : ヨシ原で覆わ れた河岸が持つ護岸機能の評価, 第 57 回年次学術講演魁講 演概要集(CD-ROM)，II-188，2002-9

(2002. 9. 30受付) 